\title{
WATER REQUIREMENTS FOR IRRIGATED SUGARCANE UNDER TRICKLE IRRIGATION SYSTEMS
}

\author{
M. Hanafy ${ }^{1}$, A. Mahrous ${ }^{2}$ and M. Z. El Garib ${ }^{3}$
}

\section{ABSTRACT}

Effect of irrigation water requirements and row spacing of surface and subsurface trickle irrigated sugarcane on soil moisture distribution, sugarcane yield, sugar percentage and water use efficiency were studied. There are three different lateral distance between plants $(L)$ used in the experiment; $0.75 \mathrm{~m}, 1.00 \mathrm{~m}$ and $1.25 \mathrm{~m}$ under four irrigation treatments; $70 \%, 85 \%, 100 \%$ and $115 \%$ from water requirements of sugarcane. Soil moisture content was affected by different water requirements and row spacing. While the average soil moisture content in the upper layer $(0-$ $20 \mathrm{~cm})$ under subsurface trickle irrigation was less than under surface trickle irrigation, it was in subsurface trickle irrigation more than in surface trickle irrigation in lower layer $(30-50 \mathrm{~cm})$. The results of this work indicated that the maximum yield production is 70 ton/fed under surface trickle irrigation system, $1.25 \mathrm{~m}$ distance between plants and at $85 \%$ of water requirements of sugarcane. Also the results indicated that the maximum yield production is 70 ton/fed under sub-surface trickle irrigation system, $1.00 \mathrm{~m}$ and $1.25 \mathrm{~m}$ distance between plants and at $100 \%$ and $85 \%$ of water requirements of sugarcane respectively. A crop coefficient curve for sugarcane was plotted for measuring crop evapotranspiration.

\section{INTRODUCTION}

There is a growing trend toward the use of trickle irrigation systems for sugarcane production in arid regions. This interest stems from the desire for achieving food security with limited resources (Hanafy and Bakeer 1994). Irrigating sugarcane presents several problems not found in irrigating other crops.

1. Prof., Ag. Eng. Dept., Faculty of Ag., Cairo Univ.

2. Assis. Prof., Ag. Eng. Dept., Faculty of Ag., Cairo Univ.

3. Agric. Engineer, Private Sector. 
The sugarcane crop is grown for 12 months, producing a vast quantity of cane per feddan, limiting physical access into fields. Traditional irrigation systems do not adapt to sugarcane with limited water. Against the background of the rapid decline in irrigation water potential and low water-use efficiency in the flood (conventional) method of irrigation, trickle irrigation has recently been introduced to cultivate sugar cane. Besides saving a substantial amount of water, it also helps to increase the productivity of crops. The objective of this study was to maximize the yield of the sugarcane under deficit irrigation water for surface and subsurface trickle irrigation systems. Stewart et al. (1976) described two possible scenarios for the different effects of deficient evapotranspiration (ETd) on crop yields. ETd may either prevail throughout the whole growing season or it is confined within a given growth period, depending on water allocation programs in the irrigation schemes or on a particular irrigation practice preferred by the individual farmer. Stewart et al. (1977) suggested equation (1) to estimate relative crop yield as a function of relative evapotranspiration deficient

$$
\text { Where: } \begin{array}{ll}
Y & =\text { expected crop yields } \\
Y_{m} & =\text { maximum yields } \\
k_{y} & =\text { crop yield response factor } \\
E T & =\text { evapotranspiration } \\
E T_{m} & =\text { maximum evapotranspiration }
\end{array}
$$

Where $\boldsymbol{k}_{\boldsymbol{y}}$ is crop yield response factor which varies depending on crop species, variety, irrigation method and management, and growth stage when deficient evapotranspiration occurs. The response factor $\boldsymbol{k}_{\boldsymbol{y}}$ measured with carefully designed field experiments gives a direct indication of a given crop being sensitive to deficient evapotranspiration (i.e. water stress), and it is the only unknown parameter to estimate maximum crop yield $Y_{m}$. The most widely used form equation (1) is

$$
1-Y \cdot Y_{m}^{-1}=k_{y}\left(1-E T \cdot E T_{m}^{-1}\right)
$$

Which is used to estimate relative yield reduction $\left(1-Y . Y_{m}^{-1}\right)$ as a 
function of relative evapotranspiration deficient $\left(1-E T \cdot E T_{m}^{-1}\right)$ if the response factor ky is known. Stewart and Hagan (1973) indicated that crop yield showed very strong linear association with $\boldsymbol{E T}$; however, they commented that irrigation water requirement (IRR), more correctly irrigation water used or applied, may be preferred over $E T$ because irrigation engineers and irrigationists in the field need $I R R$ for effective management of existing irrigation schemes or for designing and planning of future irrigation projects. However, yield response is not linearly related to IRR - it is usually a curvalinear relation (Misra, 1973; Stewart and Hagan, 1973; Tekinel and Kanber, 1979). Bruggeman et al. 2005 studied the increasing water scarcity due to population growth and urbanization is pushing the countries in the Mediterranean region to improve their irrigation water use efficiency. By evaluate a model for scheduling of supplemental irrigation based on daily climate data and to assess irrigation requirements under different irrigation management options in northern Syria. The model used the FAO daily reference evapotranpiration and dual crop coefficient procedure for estimating irrigation requirements, but an addition was made to allow the storage of soil moisture below the developing root zone of rain-fed crops. The model performed satisfactorily for three years of data from a wheat trial at Tel Hadya in northern Syria, which has an average annual rainfall of $356 \mathrm{~mm}$. The tested irrigation management options included the application of full irrigation at $50 \%$ depletion of the available soil water and irrigation of $67 \%$ of the soil water depletion at $75 \%$ of the available soil water. Abu Zeid, (1995) reported that among the early studies on yield production functions, reported a linear relation between dry matter yield and transpiration. Effects of deficient transpiration on crop growth, including stomata behavior. Yalcuk and Ozkara (1984) in Aegean Region, showed that a $40 \%$ reduction in irrigation water application would not significantly decrease the cotton yield. Bastug (1987) conducted open field irrigation experiments to study the effects of both seasonal and growth-stage specific deficient ET on cotton yield. He tested 3 growth stages of cotton: (1) vegetation, (2) flowering/yield formation and (3) ripening. The yield response factors $k_{y}$ were 0.99 for the entire season and 0.76 for flowering/yield formation stages of cotton. They indicate that the least yield reduction is obtained when deficit irrigation is confined to flowering/yield formation stages. 


\section{MATERIALS AND METHODS}

A field experiment was carried out at experimental farm of the irrigation unit, Agric. Eng. Dept., Faculty of Agric., Cairo Univ., from 2005 to 2006. The site is located at Giza Governorate. Altitude, Latitude and longitude of the area are 22.05, 30.05 $\mathrm{N}$ and 31.22 E respectively. The total area of the field is equal to $5451.6 \mathrm{~m}^{2}$ (1.298 fed.). The some chemical and physical characteristics of the experimental field soil are shown in Table (1).

Table (1): Some chemical and physical analysis of Soil samples.

\begin{tabular}{|c|c|c|c|c|c|c|c|c|c|c|}
\hline $\begin{array}{c}\text { Depth, } \\
\mathrm{cm}\end{array}$ & $\mathrm{pH}$ & $\begin{array}{c}\mathrm{EC} \\
\mathrm{ds} / \mathrm{m}\end{array}$ & $\begin{array}{c}\mathrm{HCO}_{3}^{-} \\
\mathrm{meq} / \mathrm{l}\end{array}$ & $\begin{array}{c}\mathrm{CL}^{-} \\
\mathrm{meq} / \mathrm{l}\end{array}$ & $\begin{array}{c}\mathrm{So} 4 \\
\mathrm{meq} / \mathrm{l}\end{array}$ & $\begin{array}{c}\mathrm{Ca}^{++} \\
\mathrm{meq} / \mathrm{l}\end{array}$ & $\begin{array}{c}\mathrm{K}^{+} \\
\mathrm{meq} / \mathrm{l}\end{array}$ & $\begin{array}{c}\mathrm{Mg}^{++} \\
\mathrm{meq} / \mathrm{l}\end{array}$ & $\begin{array}{c}\mathrm{Na}^{+} \\
\mathrm{meq} / \mathrm{l}\end{array}$ & $\mathrm{SAR}$ \\
\hline $00-20$ & 7.74 & 2.43 & 1.0 & 3.6 & 19.84 & 7.8 & 1.14 & 6.4 & 9.10 & 1.13 \\
$20-40$ & 7.69 & 1.92 & 0.9 & 3.0 & 15.9 & 5.6 & 0.82 & 5.4 & 7.98 & 1.20 \\
$40-60$ & 7.81 & 1.78 & 0.8 & 3.2 & 13.62 & 4.0 & 0.82 & 5.0 & 7.8 & 1.32 \\
\hline
\end{tabular}

\section{Soil moisture characteristics}

Field capacity $\%$ per volume $: 40$

Permanent wilting point $\%$ per volume $\quad: 16$

Available water $\%$ per volume $\quad: 24$

Bulk density gm/ $/ \mathrm{cm}^{3}$

$: 1.31$

Also, Table (2) shows some chemical analysis of irrigation water sample.

Table (2): Chemical and physical analysis of water sample.

\begin{tabular}{|c|c|c|c|c|c|}
\hline $\mathrm{PH}$ & 7.20 & $\mathrm{Ca}$ meq/l & 3.60 & $\mathrm{~K}$ meq/l & 0.18 \\
\hline $\mathrm{EC} \mathrm{ds} / \mathrm{m}$ & 0.83 & $\mathrm{Mg}$ meq/l & 2.60 & $\mathrm{SAR}$ & 0.54 \\
\hline $\mathrm{Cl} \mathrm{meq} / \mathrm{l}$ & 1.00 & $\mathrm{Na}$ meq/l & 0.90 & T.S.S & 0.00 \\
\hline $\mathrm{HCO}_{3} \mathrm{meq} / \mathrm{l}$ & 5.00 & $\mathrm{SO}_{4} \mathrm{meq} / \mathrm{l}$ & 1.28 & & \\
\hline
\end{tabular}

* T.S.S = Total suspended solids in irrigation water

Water was delivered from the well into closed piping system under constant pressure using pump that gives a water discharge of $15 \mathrm{~m}^{3} / \mathrm{h}$. The emitter used in the procedure was an in-line non-compensating emitter and have discharge $2.21 / \mathrm{h}, 30 \mathrm{~cm}$ spacing between emitters and $30 \mathrm{~m}$ long for all treatments. For subsurface trickle irrigation, the trickle lines placement depth was $20 \mathrm{~cm}$. 
The sugarcane crop variety was C9.

\section{Experimental design and treatment}

In the present investigation, two different trickle irrigation systems were used; one of them was surface trickle irrigation system (S) whereas other was sub-surface trickle irrigation system (SS). Also there were three different lateral distance (L) used in the experiment; $0.75 \mathrm{~m}, 1.00 \mathrm{~m}$ and $1.25 \mathrm{~m}$. The irrigation treatments were randomized with two replications.

Table (3): Experimental design and treatment

\begin{tabular}{|c|c|c|c|c|c|c|c|}
\hline $\begin{array}{c}\text { Irrigation } \\
\text { system }\end{array}$ & \multicolumn{3}{|c|}{$\begin{array}{c}\text { Surface } \\
\text { trickle irrigation }(S)\end{array}$} & \multicolumn{3}{|c|}{$\begin{array}{c}\text { Sub-Surface } \\
\text { trickle irrigation (SS) }\end{array}$} & Traditional \\
\hline $\begin{array}{c}\text { Lateral } \\
\text { Length }(\mathbf{L})\end{array}$ & $\begin{array}{c}\text { L1 } \\
0.75 \mathrm{~m}\end{array}$ & $\begin{array}{c}\mathrm{L} 2 \\
1.00 \mathrm{~m}\end{array}$ & $\begin{array}{c}\mathrm{L3} \\
1.25 \mathrm{~m}\end{array}$ & $\begin{array}{c}\text { L1 } \\
0.75 \mathrm{~m}\end{array}$ & $\begin{array}{c}\mathrm{L} 2 \\
1.00 \mathrm{~m}\end{array}$ & $\begin{array}{c}\mathrm{L3} \\
1.25 \mathrm{~m}\end{array}$ & $\begin{array}{c}\text { Surface } \\
\text { irrigation }\end{array}$ \\
\hline$E T 1=0.70$ & SL1E1 & SL2E1 & SL3E1 & SSL1E1 & SSL2E1 & SSL3E1 & \multirow{4}{*}{$\begin{array}{l}\overline{0} \\
\text { ¿0 }\end{array}$} \\
\hline$E T 2=0.85$ & SL1E2 & SL2E2 & SL3E2 & SSL1E2 & SSL2E2 & SSL3E2 & \\
\hline$E T 3=1.00$ & SL1E3 & SL2E3 & SL3E3 & SSL1E3 & SL2E3S & SSL3E3 & \\
\hline ET4 $=1.15$ & SL1E4 & SL2E4 & SL3E4 & SSL1E4 & SSL2E4 & SSL3E4 & \\
\hline
\end{tabular}

The soil samples were taken from different locations by Thetameter instrument (at head, 1/3, 2/3 and tail of lateral). The location was defined according to its $\mathrm{x}, \mathrm{y}$ and $\mathrm{z}$ coordinates with respect to the emitter. The sample location with respect to the $\mathrm{x}$-direction were taken at $0,5,10$ and $15 \mathrm{~cm}$ for all treatments. With respect to the y-direction, perpendicular to the trickle line, the sample locations were taken at 18.75 and $37.5 \mathrm{~cm}$ for treatments have $0.75 \mathrm{~m}$ plant distance, 25 and $50 \mathrm{~cm}$ for treatments have $1.00 \mathrm{~m}$ plant distance and 31.25 and $62.5 \mathrm{~cm}$ for treatments have $1.25 \mathrm{~m}$ plant distance. For each of these locations, soil samples were collected from different depths from soil surface, which were (0-10), (10-20), (20$30),(30-40)$ and (40-50) $\mathrm{cm}$. Before starting the experiment, the initial moisture content of the soil was determined. It should be noted that the initial soil moisture content before water application ranged from 24.4 to $29.6 \%$ by weight.

Measurements and calculations:

Various measurements had been taken into consideration

\section{Plant measurements}


The sugarcane stem length, diameter, sugar percentage and production were measured using steel tape (5 m length), vernier caliper (accuracy $0.1 \mathrm{~mm}$ ), refractometer and spring balance, respectively.

\section{Water use efficiency (WUE)}

Water use efficiency was taken into consideration when irrigation methods are being compared or irrigation scheduling is being evaluated. For irrigation water use efficiency (Kanber et al., 1993), net irrigation amount was used in equation (3):

$$
W U E=\frac{Y}{S A W}
$$

In which, $S A W$ is the seasonal amount of applied water to one feddan as cubic meter and $Y$ is the sugarcane yield in $\mathrm{kg} / \mathrm{fed}$.

The seasonal amount of applied water $(S A W)$ can be calculated from eq. (4):

$$
S A W=\sum_{i=1}^{12} Q_{i}
$$

In which, $Q_{i}$ is the water applied to one feddan per day during one month

3. Calculate the water requirements for sugarcane crop by using CROPWAT Program

The actual crop water requirement was estimated by equation (5)

$$
\mathrm{ET}_{\mathrm{c}}=\mathrm{K}_{\mathrm{c}} \times \mathrm{ET}_{\mathrm{o}}
$$

For different months based on crop growth stages and climatic data (table 4) using the model suggested by Penman-Monteith's formula (Allen $\boldsymbol{e t}$ al., 1998). Amounts of irrigation water used after planting was 1155.28 $\mathrm{mm}$ for the growing season (for traditional or surface irrigation).

Table (4): Average climatic data 2000/2006 of Giza Governorate.

\begin{tabular}{|c|c|c|c|c|c|c|c|c|c|c|c|c|}
\hline Item & Jan & Feb & Mar & Apr & May & Jun & Jul & Aug & Sep & Oct & Nov & Dec \\
\hline MMax T, $^{\mathbf{0}} \mathbf{C}$ & 19.0 & 20.2 & 23.4 & 25.9 & 26.1 & 24.9 & 26.9 & 27.7 & 26.2 & 28.2 & 24.6 & 20.2 \\
\hline MMin.T, $^{\mathbf{0}} \mathbf{C}$ & 9.6 & 10.3 & 12.9 & 15.1 & 19.9 & 21.6 & 23.8 & 24.5 & 22.7 & 19.0 & 15.6 & 11.1 \\
\hline MRH, \% $^{2}$ & 57.3 & 53.9 & 52.9 & 48.3 & 44.4 & 44.6 & 56.8 & 55.4 & 53.5 & 58.5 & 59.3 & 60.1 \\
\hline WS, m/s & 1.4 & 1.9 & 3.2 & 3.4 & 2.3 & 2.4 & 8.1 & 9.5 & 9.4 & 8.0 & 7.7 & 6.8 \\
\hline DS, h & 10.0 & 10.0 & 10.5 & 11.0 & 11.5 & 11.5 & 12.0 & 12.0 & 11.5 & 11.5 & 11.0 & 10.5 \\
\hline
\end{tabular}

$\mathrm{MM}_{\mathrm{ax}} \mathrm{T}=$ mean max. temp, $\mathrm{MM}_{\mathrm{in}} \mathrm{T}=$ mean min. temp, $\mathrm{MRH}=$ mean $\mathrm{RH}, \mathrm{WS}=$ wind speed and DS= daily sunshine

\section{Sugar-water use efficiency $(S W U E)$}

Misr J. Ag. Eng., October 2008 
The sugar-water use efficiency ( $S W U E$ ) was calculated from equation (6)

$$
S W U E=\frac{Y * S p}{S A W}
$$

Where:

$$
\begin{aligned}
\text { SWUE } & =\text { Sugar-water use efficiency, ton } / \mathrm{m}^{3} \\
\mathrm{Y} & =\text { Sugarcane stem yield }, \text { ton } / \mathrm{fed} \\
\mathrm{Sp} & =\text { Sugar concentration in the sugarcane stem, } \% \\
\text { SAW } & =\text { Seasonal amount of applied water, } \mathrm{m}^{3} / \mathrm{fed} .
\end{aligned}
$$

\section{RESULTS AND DISCUSSION}

\section{1- Sugarcane characteristics and yield}

Table (5) shows the following under surface trickle irrigation:

- The minimum stem length was $288 \mathrm{~cm}$ for treatment SL1E2 and the maximum stem length was $378 \mathrm{~cm}$ for treatment SL3E3. The stem length in treatment SL3E3 was higher than the stem length in control treatment $(305 \mathrm{~cm})$ by $23.93 \%$.

Table (5): The plant measurements of sugarcane under surface trickle irrigation system.

\begin{tabular}{|c|c|c|c|c|}
\hline \multirow{2}{*}{ Treatments } & \multicolumn{4}{|c|}{ Plant measurements } \\
\cline { 2 - 5 } & $\begin{array}{c}\text { Stem length, } \\
\text { cm }\end{array}$ & $\begin{array}{c}\text { Stem diameter, } \\
\mathbf{c m}\end{array}$ & $\begin{array}{c}\text { Sugar percentage, } \\
\text { \% }\end{array}$ & $\begin{array}{c}\text { Production, } \\
\text { tonlfed }\end{array}$ \\
\hline SL1E1 & 341 & 2.5 & 13.6 & 54 \\
\hline SL1E2 & 288 & 2.45 & 13.3 & 62 \\
\hline SL1E3 & 370 & 2.9 & 13.1 & 65 \\
\hline SL1E4 & 310 & 2.6 & 12.5 & 61 \\
\hline SL2E1 & 351 & 2.4 & 13.2 & 52 \\
\hline SL2E2 & 360 & 3.34 & 13.4 & 67 \\
\hline SL2E3 & 374 & 3 & 13 & 70 \\
\hline SL2E4 & 315 & 2.8 & 12.3 & 63 \\
\hline SL3E1 & 358 & 2.6 & 13.5 & 49 \\
\hline SL3E2 & 373 & 2.5 & 13.2 & 70 \\
\hline SL3E3 & 378 & 3.4 & 13.2 & 68 \\
\hline SL3E4 & 320 & 3.1 & 12.4 & 58 \\
\hline Control & 305 & 2.8 & 11.0 & 50 \\
\hline
\end{tabular}


- The minimum stem diameter was $2.4 \mathrm{~cm}$ for treatment SL2E1 and the maximum stem diameter was $3.4 \mathrm{~cm}$ for treatment SL3E3. The stem diameter in treatment SL3E3 was higher than the stem diameter in control treatment $(2.8 \mathrm{~cm})$ by $21.43 \%$.

- The minimum sugar percentage was $12.3 \%$ for treatment SL2E4 and the maximum sugar percentage was $13.6 \%$ for treatment SL1E1. The sugar percentage in treatment SL1E1 was higher than the sugar percentage in control treatment $(11 \%)$ by $23.64 \%$.

- The minimum sugarcane production was 49 ton treatment SL3E1 and the maximum production was 70 ton for both treatments SL2E3 and SL3E2 respectively. The production in treatments SL2E3 and SL3E2 was higher than the production in control treatment ( 50 ton/fed) by 40 $\%$.

Table (6) shows the following under subsurface trickle irrigation:

- The minimum stem length was $331 \mathrm{~cm}$ for treatment SSL1E2 and the maximum stem length is $382 \mathrm{~cm}$ for treatment SSL3E2. The stem length in treatment SSL2E3 was higher than the stem length in control treatment $(305 \mathrm{~cm})$ by $25.25 \%$.

- The minimum stem diameter was $2.41 \mathrm{~cm}$ for both treatments SSL1E2 and SSL2E2 respectively and the maximum stem diameter was $3.6 \mathrm{~cm}$ for treatment SSL3E3. The stem diameter in treatment SSL3E3 was higher than the stem diameter in control treatment $(2.8 \mathrm{~cm})$ by $28.57 \%$.

- The minimum sugar percentage was $12.6 \%$ for treatment SSL2E4 and the maximum sugar percentage was $13.7 \%$ for both treatments SSL1E1 and SSL3E1 respectively.

- The sugar percentage in treatments (SSL1E1 and SSL3E1) was higher than the sugar percentage in control treatment (11\%) by $24.55 \%$.

- The minimum production was 50 tonlfed for both treatments SSL2E1 and SSL3E1 respectively and the maximum production is 72 ton for treatment SSL2E3. The production in treatment SSL2E3 was higher than the production in control treatment ( 50 tonlfed) by $44 \%$. 
Table (6): The plant measurements of sugarcane under sub-surface trickle irrigation system

\begin{tabular}{|c|c|c|c|c|}
\hline \multirow{2}{*}{ Treatments } & \multicolumn{4}{|c|}{ Plant measurements } \\
\cline { 2 - 5 } & $\begin{array}{c}\text { Stem length, } \\
\mathbf{c m}\end{array}$ & $\begin{array}{c}\text { Stem diameter, } \\
\mathbf{c m}\end{array}$ & $\begin{array}{c}\text { Sugar } \\
\text { percentage, \% }\end{array}$ & $\begin{array}{c}\text { Production, } \\
\text { tonlfed }\end{array}$ \\
\hline SSL1E1 & 338 & 2.6 & 13.7 & 55 \\
\hline SSL1E2 & 331 & 2.41 & 13.2 & 62 \\
\hline SSL1E3 & 372 & 3 & 13 & 65 \\
\hline SSL1E4 & 325 & 2.7 & 13 & 64 \\
\hline SSL2E1 & 355 & 2.5 & 12.9 & 50 \\
\hline SSL2E2 & 364 & 2.41 & 13.5 & 66 \\
\hline SSL2E3 & 378 & 3.2 & 13.2 & 72 \\
\hline SSL2E4 & 324 & 3 & 12.6 & 62 \\
\hline SSL3E1 & 356 & 2.8 & 13.7 & 50 \\
\hline SSL3E2 & 382 & 2.7 & 13.2 & 68 \\
\hline SSL3E3 & 377 & 3.6 & 13.4 & 67 \\
\hline SSL3E4 & 316 & 3.2 & 12.8 & 57 \\
\hline Control & 305 & 2.8 & 11.0 & 50 \\
\hline
\end{tabular}

\section{2- Sugar-water use efficiency}

Figure (1-a) shows the following under surface trickle irrigation:

- The minimum $S W U E$ was $0.85 \mathrm{~kg} / \mathrm{m}^{3}$ for both treatments SL1E4 and SL3E4 and the maximum value was $1.60 \mathrm{~kg} / \mathrm{m}^{3}$ for treatment SL3E2. The SWUE in treatments SL3E2 was higher than the sugar percentage efficiency in control treatment $\left(0.44 \mathrm{~kg} / \mathrm{m}^{3}\right)$ by $263.64 \%$.
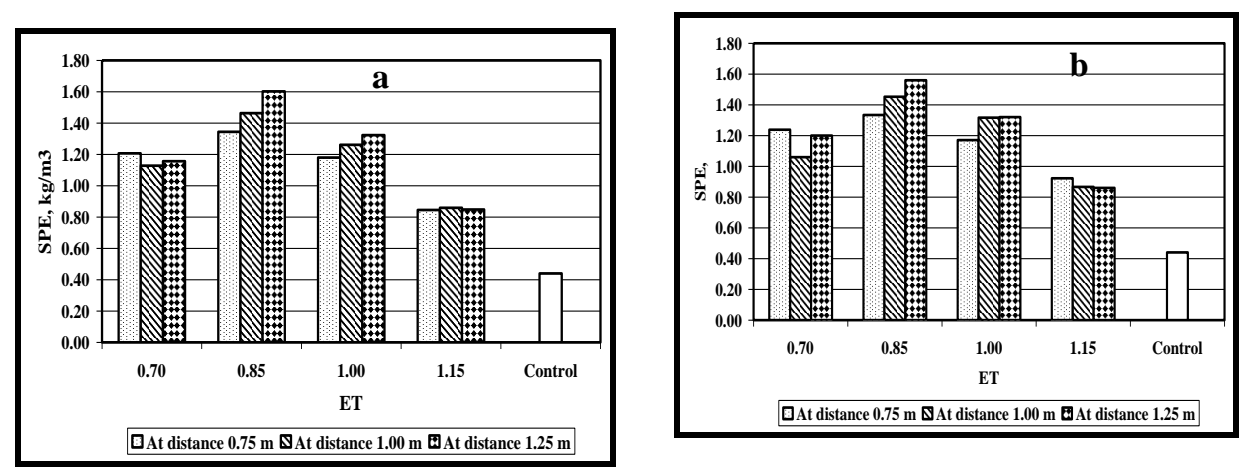

Figure (1): Effect of water requirements on sugar-water use efficiency under

(a) surface trickle irrigation (b) subsurface trickle irrigation

Misr J. Ag. Eng., October 2008 
Figure (1-b) shows the following under sub-surface trickle irrigation:

- The minimum $S W U E$ was $0.86 \mathrm{~kg} / \mathrm{m}^{3}$ for treatment SSL4E3 the maximum SWUE was $1.56 \mathrm{~kg} / \mathrm{m}^{3}$ for treatment SSL2E3. The $S W U E$ in treatments SSL2E3 was higher than the SWUE in control treatment $\left(0.44 \mathrm{~kg} / \mathrm{m}^{3}\right)$ by $254.55 \%$.

\section{3- Soil moisture content}

The percentage of water found in the soil profile at different distances from the emitter at the end of irrigation time tabulated in tables (7 and 8) and figures (5 and 6).

Table (7) and figure (5) show the following under surface trickle irrigation:

- The first and the second vertical layer in the Y-direction $(0-10 \mathrm{~cm})$ and $(10-20 \mathrm{~cm})$ had $55 \%$ of the total applied water volume for the treatment SL3E1, while it had 53, 51, 52, 51, 54, 51, 51, 52, 51, 52 and $50 \%$ of the total applied water volume for other treatments of SL1E1, SL1E2, SL1E3, SL1E4, SL2E1, SL2E2, SL2E3, SL2E4, SL3E2, SL3E3 and SL3E4 respectively.

- The third vertical layer in the Y-direction (20 -30 cm) had $25 \%$ of the total applied water volume for the treatments SL1E3 and SL3E2, while it had 22, 24, 24, 23, 24, 24, 23, 20, 24 and $24 \%$ of the total applied water volume for other treatments of SL1E1, SL1E2, SL1E4, SL2E1, SL2E2, SL2E3, SL2E4, SL3E1, SL3E3 and SL3E4 respectively.

- The total applied water volume for all treatments in the last vertical layer increased with increasing distances between laterals and with increasing ET. Also for the vertical Y-direction, the water moved further vertically by increasing the distance between plants.

- In the treatments which had the same distance between laterals in the first layers, the total applied water volume decreased with increasing ET.

- The total applied water volume for all treatments in the forth and fifth vertical layers $(30-40 \mathrm{~cm})$ and $(40-50 \mathrm{~cm})$ had very little percentage of water content.

Table (8) and figure (6) show the following under subsurface trickle irrigation: 
- The second and the third vertical layer in the Y-direction $(10-20 \mathrm{~cm})$ and $(20-30 \mathrm{~cm})$ had $44 \%$ of the total applied water volume for most the treatments, while it had 43, 42, 42 and $43 \%$ of the total applied water volume for other treatments of SL1E2, SL3E1, SL3E2 and SL3E4, respectively.

- The first vertical layer in the Y-direction $(0-10 \mathrm{~cm})$ had $21 \%$ of the total applied water volume for most the treatments, while it had 20, 20, 20,20 and $19 \%$ of the total applied water volume for other treatments of SL2E1, SL2E2, SL2E3, SL3E3 and SL3E4, respectively.

- The maximum percentage of total applied water volume found in second layer $(10-20 \mathrm{~cm})$ for most the treatments except the treatments SL3E1, SL3E2 and SL3E4 which the maximum percentage of total applied water volume for them found in third layer $(20-30 \mathrm{~cm})$.

Table (7): Percentage of water volume stored in soil profile at different distances from emitter in surface trickle irrigation system.

\begin{tabular}{|c|c|c|c|c|c|c|c|c|c|c|c|c|}
\hline \multicolumn{13}{|c|}{ Treatments } \\
\hline \multirow{2}{*}{$\begin{array}{c}\text { Depth, } \\
\text { cm }\end{array}$} & SL1E1 & SL1E2 & SL1E3 & SL1E4 & SL2E1 & SL2E2 & SL2E3 & SL2E4 & SL3E1 & SL3E2 & SL3E3 & SL3E4 \\
\hline & \multicolumn{12}{|c|}{ Vertical (Y-direction) at the end of irrigation } \\
\hline 0 - 10 & 0.27 & 0.26 & 0.25 & 0.25 & 0.28 & 0.26 & 0.26 & 0.27 & 0.3 & 0.25 & 0.25 & 0.24 \\
\hline $10-20$ & 0.26 & 0.26 & 0.26 & 0.26 & 0.26 & 0.25 & 0.25 & 0.26 & 0.25 & 0.26 & 0.26 & 0.25 \\
\hline 20 - 30 & 0.15 & 0.14 & 0.14 & 0.14 & 0.14 & 0.14 & 0.14 & 0.14 & 0.15 & 0.14 & 0.13 & 0.15 \\
\hline $30-40$ & 0.1 & 0.11 & 0.09 & 0.11 & 0.09 & 0.11 & 0.11 & 0.11 & 0.1 & 0.11 & 0.11 & 0.11 \\
\hline $40-50$ & 0.53 & 0.51 & 0.52 & 0.51 & 0.54 & 0.51 & 0.51 & 0.52 & 0.55 & 0.51 & 0.52 & 0.5 \\
\hline Dist., cm & \multicolumn{12}{|c|}{ Lateral (X-direction) at the end of irrigation } \\
\hline $0-5$ & 0.37 & 0.39 & 0.38 & 0.39 & 0.38 & 0.38 & 0.38 & 0.38 & 0.34 & 0.36 & 0.36 & 0.36 \\
\hline $5-10$ & 0.31 & 0.32 & 0.32 & 0.32 & 0.32 & 0.32 & 0.32 & 0.31 & 0.34 & 0.34 & 0.34 & 0.34 \\
\hline $10-15$ & 0.32 & 0.29 & 0.29 & 0.29 & 0.3 & 0.3 & 0.3 & 0.31 & 0.32 & 0.3 & 0.31 & 0.31 \\
\hline Dist., cm & \multicolumn{12}{|c|}{ Lateral (Z-direction) at the end of irrigation } \\
\hline $0-1 / 4$ & 0.53 & 0.51 & 0.53 & 0.53 & 0.52 & 0.52 & 0.52 & 0.49 & 0.53 & 0.53 & 0.52 & 0.5 \\
\hline $1 / 4-1 / 2$ & 0.47 & 0.49 & 0.47 & 0.47 & 0.48 & 0.48 & 0.48 & 0.51 & 0.47 & 0.47 & 0.48 & 0.5 \\
\hline
\end{tabular}

- In the treatments which had the same distance between laterals in the first layers, the total applied water volume decreased with increasing ET.

- The total applied water volume for all treatments in the forth and fifth vertical layers $(30-40 \mathrm{~cm})$ and $(40-50 \mathrm{~cm})$ had more percentage of water content than the forth and fifth vertical layers $(30-40 \mathrm{~cm})$ and $(40-50 \mathrm{~cm})$ in surface trickle irrigation system. 
Table (8): Percentage of water volume stored in soil profile at different distances from emitter in subsurface trickle irrigation

\begin{tabular}{|c|c|c|c|c|c|c|c|c|c|c|c|c|}
\hline \multirow{3}{*}{$\begin{array}{l}\text { Depth, } \\
\text { cm }\end{array}$} & \multicolumn{11}{|c|}{ system. } & \\
\hline & $\begin{array}{c}\text { SSL1 } \\
\text { E1 }\end{array}$ & $\begin{array}{c}\text { SSL1 } \\
\text { E2 }\end{array}$ & $\begin{array}{c}\text { SSL1 } \\
\text { E3 }\end{array}$ & $\begin{array}{c}\text { SSL1 } \\
\text { E4 }\end{array}$ & $\begin{array}{c}\text { SSL2 } \\
\text { E1 }\end{array}$ & $\begin{array}{c}\text { SSL2 } \\
\text { E2 }\end{array}$ & $\begin{array}{c}\text { SSL2 } \\
\text { E3 }\end{array}$ & $\begin{array}{c}\text { SSL2 } \\
\text { E4 }\end{array}$ & $\begin{array}{c}\text { SSL3 } \\
\text { E1 }\end{array}$ & $\begin{array}{c}\text { SSL3 } \\
\text { E2 }\end{array}$ & $\begin{array}{c}\text { SSL3 } \\
\text { E3 }\end{array}$ & $\begin{array}{c}\text { SSL3 } \\
\text { E4 }\end{array}$ \\
\hline & \multicolumn{12}{|c|}{ Vertical (Y-direction) at the end of irrigation } \\
\hline $\mathbf{0}-10$ & 0.21 & 0.21 & 0.21 & 0.21 & 0.2 & 0.2 & 0.2 & 0.21 & 0.21 & 0.21 & 0.2 & 0.19 \\
\hline $10-20$ & 0.23 & 0.22 & 0.22 & 0.22 & 0.22 & 0.22 & 0.22 & 0.22 & 0.2 & 0.2 & 0.23 & 0.21 \\
\hline 20 - 30 & 0.21 & 0.21 & 0.22 & 0.22 & 0.22 & 0.22 & 0.21 & 0.21 & 0.21 & 0.22 & 0.21 & 0.22 \\
\hline $30-40$ & 0.19 & 0.19 & 0.2 & 0.2 & 0.19 & 0.19 & 0.2 & 0.19 & 0.2 & 0.2 & 0.2 & 0.2 \\
\hline $40-50$ & 0.16 & 0.17 & 0.16 & 0.15 & 0.16 & 0.16 & 0.17 & 0.17 & 0.18 & 0.17 & 0.16 & 0.17 \\
\hline Dist., cm & \multicolumn{12}{|c|}{ Lateral (X-direction) at the end of irrigation } \\
\hline $0-5$ & 0.33 & 0.35 & 0.34 & 0.34 & 0.35 & 0.35 & 0.34 & 0.34 & 0.34 & 0.34 & 0.35 & 0.35 \\
\hline $5-10$ & 0.34 & 0.34 & 0.34 & 0.34 & 0.34 & 0.34 & 0.34 & 0.34 & 0.34 & 0.34 & 0.34 & 0.34 \\
\hline $10-15$ & 0.33 & 0.31 & 0.32 & 0.32 & 0.31 & 0.31 & 0.32 & 0.32 & 0.32 & 0.32 & 0.31 & 0.31 \\
\hline Dist., $\mathbf{c m}$ & \multicolumn{12}{|c|}{ Lateral (Z-direction) at the end of irrigation } \\
\hline 0 - 1/4 & 0.52 & 0.53 & 0.52 & 0.53 & 0.53 & 0.52 & 0.54 & 0.54 & 0.54 & 0.53 & 0.52 & 0.52 \\
\hline $1 / 4-1 / 2$ & 0.48 & 0.47 & 0.48 & 0.47 & 0.47 & 0.48 & 0.46 & 0.46 & 0.46 & 0.47 & 0.48 & 0.48 \\
\hline
\end{tabular}

\section{4- Crop coefficient:}

Figure (2) shows the crop coefficient curve for sugarcane, for different crop-growing stages, plotted from emergence period till harvest. The crop coefficient for emergence period was calculated according to potential evapotranspiration for Giza area for July $(4.85 \mathrm{~mm} /$ day $)$ and irrigation frequency each day.

The crop developed stage starts after 30 days from the initial stage (emergence stage) to 60 days, the mid-season stage starts after 60 days from the end of initial stage to the first harvest day, and the late season stage starts from the end of mid season days till the end of harvest.

The crop coefficient curve for sugarcane was plotted for different cropgrowing stages. The crop coefficient for trickle irrigated sugarcane was found to be 0.40 for initial stage, 0.40 to 1.25 for developed stage, 1.25 for mid season stage and 1.25 to 0.75 for late season stage 


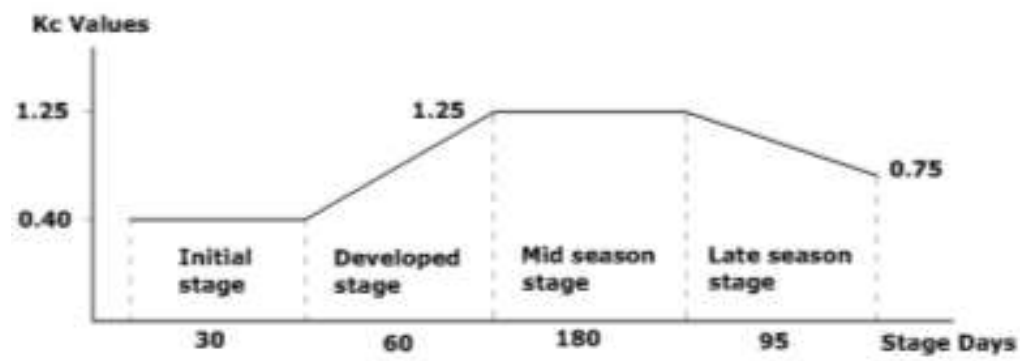

Figure (2): Crop coefficient curve from transplanting day to harvest for sugarcane using the model suggested by Penman-Monteith's formula (Allen et al., 1998).

\section{CONCLUSION}

The aim of this work is to study the effect of different water requirements and row spacing on soil moisture distribution, sugarcane yield, sugar percentage and water use efficiency and to determine crop coefficient for trickle irrigated sugarcane. The experiment comprised two trickle lateral installations (surface and subsurface at $20 \mathrm{~cm}$ from the soil surface), three row spacing $(75,100$ and $125 \mathrm{~cm})$ and four levels of water requirement (70, 85, 100 and $115 \%$ from sugarcane water requirements). The following conclusion can be made from this investigation:

1. The values of the plant measurements of sugarcane (stem length and diameter, sugar percentage and production) in surface trickle irrigation were lower than the values of the plant measurements of sugarcane in subsurface trickle irrigation system.

2. The treatment SSL2E3 in subsurface trickle irrigation system had the maximum production ( $72 \mathrm{ton} / \mathrm{fad}$.), while the maximum production in surface trickle irrigation system has 70 ton/fad in treatments SL2E3 and SL3E2.

3. The water use efficiency at the maximum production in subsurface trickle irrigation system was $100.25 \mathrm{~m} 3 /$ ton, while in surface trickle irrigation system was $82.38 \mathrm{~m}^{3} /$ ton.

4. The maximum percentage of total applied water volume was found in second layer $(10-20 \mathrm{~cm})$ in subsurface trickle irrigation system, while it was found in first layer $(0-10 \mathrm{~cm})$ in surface trickle irrigation system. 
5. The crop coefficient curve for sugarcane was plotted for different crop-growing stages. The crop coefficient for trickle irrigated sugarcane was found to be 0.40 for initial stage, 0.40 to 1.25 for developed stage, 1.25 for mid season stage and 1.25 to 0.75 for late season stage.

\section{REFERENCES}

Abu Zeid, M. 1995. International water-save programs and water-save activities. In: Hamdy A (Ed) Water Saving: Prospects and Challenges (1, pp. 1-18) Cairo, Egypt.

Allen, R.G., L.S. Pereira, D. Raes and M. Smith, 1998. Crop evapotranspiration. Guidelines for computing crop water requirements. FAO irrigation and Drainage. Paper No. 56, FAO, Rome, Italy, pp: 300.

Bastug, R. 1987. A study on determining the water production functions of cotton under Cukurova conditions (PhD.). Cukurova Univ., Adana, IIT. and Drain. Dept (pp. 120).

Bruggeman, A., I. McCann, T. Oweis and M. Pala. 2005. Improved decision making for deficit irrigation of wheat in northern Syria. Published by the American Society of Agricultural and Biological Engineers, St. Joseph, Michigan www.asabe.org.

Hanafy, M. and Bakeer., G. 1994. Optimum trickleline placement depth in subsurface trickle irrigation in clay soils. Misr, J. Ag. Eng., 11 (4): October, 1994.

Kanber, R., Onder, S., M. Koksal, and Waetherhead, E. K., (1993). Comparison of surge and continuous furrow methods in Harran Plain in GAP area. Final report, on Irr. And Soil Project. Adana, 52 p.

Misra, R. D. 1973. Response of corn to different sequences of water stress as measured by evapotranspiration deficits. Ph.D. Thesis, Univ. of California, Davis

Stewart, N., and R. M. Hagan.1973. Functions to predict effects of crops water deficits. J. Irrig. Div. Am. Soc. Civ. Eng. 99: 421-439

Stewart, N., R. M. Hagan and W. O. Pruitt. 1976. Production functions and predicted irrigation programs for principal crops as required for water resources planning and increased water use efficiency. Final Rep. U.S. Dept. of Interior, Bur. of Reclamation, Washington, D.C. 
Stewart, N., R. H. Cuenca, W. O. Pruitt, R. M. Hagan and J. Tosso. 1977. Determination and utilization of water production functions for principal California crops. W-67 Calif Contributing Proj. Rep. University of California, Davis

Tekinel O \& Kanber $R$ 1979. Cukurovakosullarinda kisintili su kullanma durumunda pamugun su tuketimi ve verimi (pp 39). TOPRAKSU Arast. Enst. Yay.98(48), Tarsus Turkey.

Yalcuk, H. and H. M. Ozkara. 1984. The effects of omitted irrigation on cotton production in West Anatolia Region. Soil-Water Res. Ins. Pup. No. 107, Izmir (pp. 35).

\section{الملخص العربيى}

الأحتياجات المائية لإنتاج محصول القصب تحت نظم الرى بالتنقيط

\section{محمد حنفى حسن' أحمد محروس حسن" محد زكريا الغريب"}

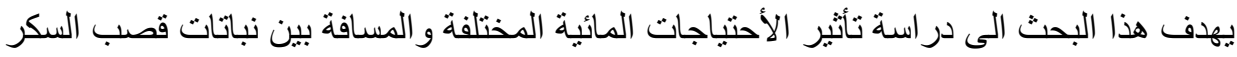

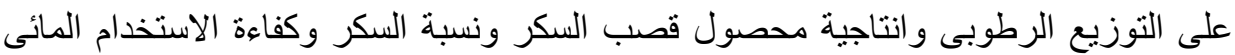

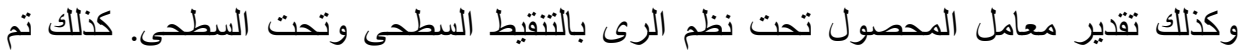

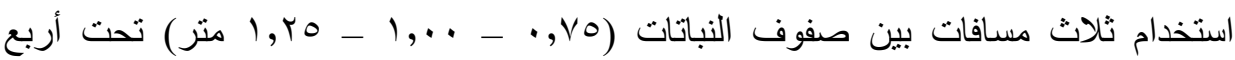

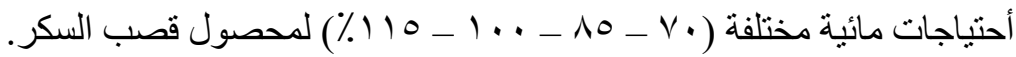

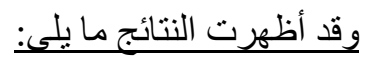
(.كانت قيم القياسات النباتية لمحصول القصب (طول وقطر الساق - نسبة السكر - الانتاجية)

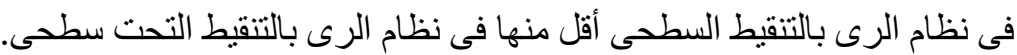

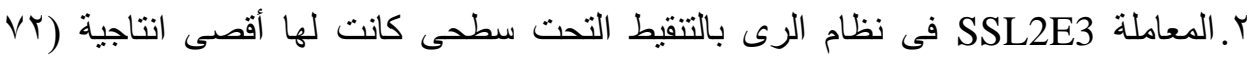

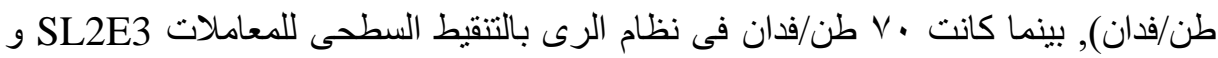

.SL3E2

r.كانت كفاءة الاستخدام المائى عند أقصى انتاجية فى نظام الرى بالتنقيط التحت سطحى

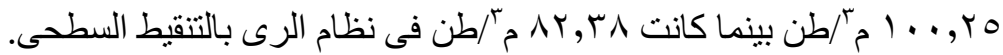

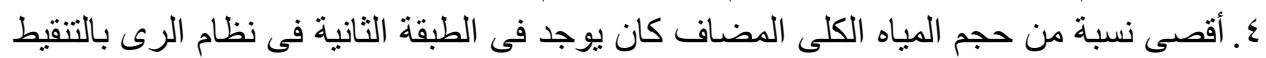

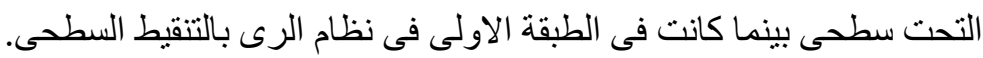

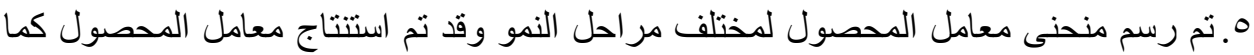

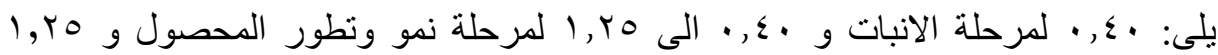

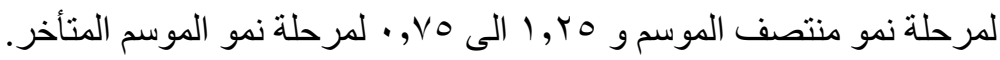

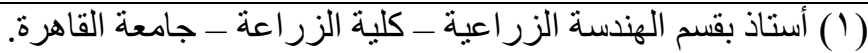

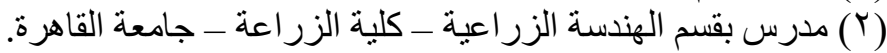
(r) (r) مهندس زر اعى - القطاع الخاص. 